\title{
COMPARATIVE ANALYSIS OF THE EFFECTS OF MELOXICAM AND FLUNIXIN MEGLUMINE ON RENAL FUNCTION OF WISTAR RATS
}

\author{
Maria Fernanda Torres ${ }^{1}$, Raquel Carneiro Silva², João Armando Brancher ${ }^{2}$, Danielle \\ Malheiros $^{2}$, Édison Luiz Prisco Farias ${ }^{1}$, Ana Tereza Bittencourt Guimarães ${ }^{1}$ \\ 1 UFPR \\ 2 UP \\ Correspondência: João Armando Brancher: brancher@up.com.br
}

\begin{abstract}
This study evaluated the renal function of rats subjected to treatment with meloxicam (ME) and flunixin meglumine (FM). Sixty six Wistar rats were divided into three groups $(n=22)$. The control group received physiological solution, while the groups treated with ME and MF received two subcutaneous doses of 2 and $1.1 \mathrm{mg} / \mathrm{kg}$ of the medication, respectively. All animals were subjected to the collection $2 \mathrm{ml}$ of blood at the beginning and end of the study to further detect the levels of urea and creatinine. Double-factor ANOVA test was applied on these data using a significance level $\leq$ 0.05. The conclusion was that the use of both drugs in therapeutic doses caused significant increase in the plasma urea level. The values of the plasma creatinine were considered equivalent between the groups in all periods.
\end{abstract}

Keywords: analgesia; laboratory animals; experimentation animals

\section{ANÁLISE COMPARATIVA DO EFEITO DO MELOXICAM E DO FLUNIXIN MEGLUMINE SOBRE A FUNÇÃO RENAL DE RATOS WISTAR}

RESUMO: Avaliou-se a função renal de ratos Wistar submetidos ao tratamento com meloxicam (ME) e flunixin meglumine (FM). Foram utilizados 66 ratos Wistar distribuídos em três grupos $(n=22)$. O grupo controle recebeu solução fisiológica, enquanto os grupos tratados com ME e FM receberam duas doses de 2 e $1,1 \mathrm{mg} / \mathrm{Kg}$, respectivamente, da medicação por via subcutânea. Todos os animais foram submetidos à coleta de $2 \mathrm{~mL}$ de sangue no início e ao fim do estudo para posterior detecção dos níveis de uréia e creatinina plasmáticas. A partir destes dados foi feita a aplicação do teste ANOVA-fator duplo. O nível de significância utilizado foi $\leq 0,05$. Conclui-se que $o$ uso de ambos os medicamentos nas dosagens terapêuticas causou aumento significativo na concentração de uréia plasmática, porém a creatinina plasmática permaneceu equivalente em todos os grupos durante o período de estudo.

Palavras-chave: analgesia; animais de laboratório; experimentação animal 


\section{INTRODUCTION}

The control of pain in laboratory animals is an ethical and legal responsibility of researchers and has become a growing concern in view of the importance of animal welfare for the maintenance of their physiological, psychological and behavioral conditions (Liles \& Flecknell, 1992), also minimizes animal suffering and distress (ILAR, 2011). The drugs used for this purpose are formulated for use in humans, pets or farm animals and, therefore, the doses used in laboratory animals are usually often extrapolations (King \& Miller, 1997).

Various analgesic drugs are available for use in laboratory animals and can be classified into three groups: i. agents acting on the central nervous system, ii. substances that block the impulses in nociceptors and, iii. agents that inhibit the production of chemical mediators of inflammation. The last group is represented by nonsteroidal anti-inflammatory drugs (NSAIDs) providing analgesia sufficient to relieve postoperative pain without the side effects of opioids (Liles \& Flecknell, 1992).

There are over 50 different NSAIDs on the market that share therapeutic activities and side effects. The mechanism of action of NSAIDs is related to inhibition of the enzyme cyclooxygenase (COX) that acts in the production of prostaglandins, prostacyclins and thromboxanes from arachidonic acid or linoleic acid (Ruiz et al., 2002; Hinz et al., 2006). Flunixin meglumine (FM) is an NSAID that was introduced in veterinary medicine in the late 1970 s as an effective alternative for the treatment of musculoskeletal and colic in horses (Macallister et al., 1993). Meloxicam (ME) is a NSAID known for its potent anti-inflammatory and analgesic being used in both humans and non humans (Hueza, 2008).
In humans, the use of NSAIDs in hospitalized patients is a cause of acute renal failure (ARF) and there is a consensus about risks and side effects on the kidneys when prescribing these drugs in patients with kidney damage (Costa et al., 2003).

Given the growing concern for the welfare of laboratory animals and, consequently, to control the pain caused by surgical procedures performed in rats, the search for anti-inflammatory insurance to their metabolism has increased. Because of this, the present study was carried out to evaluate the safety of FM and ME for renal physiology of rats.

\section{MATERIAL AND METHODS}

Sixty six healthy, adult female Wistar rats weighing $274 \mathrm{~g}( \pm 31 \mathrm{~g})$, aged 4-5 months were used in this study. The animals had free access to a standard commercial diet, water and were kept in rooms maintained at $25^{\circ} \mathrm{C}$ ).

At the beginning of the experiment the animals were sedated with isoflurane and submitted to blood collection by intracardiac puncture. The animals were divided randomly in three different groups; each group consisted of twenty-two rats. Control group (CG) was treated with subcutaneous injection with physiological solution $(2 \mathrm{~mL} / \mathrm{kg})$, while groups ME and FM were injected subcutaneously with meloxicam (2 $\mathrm{mg} / \mathrm{kg}$ ) (Teixeira, 2010), and flunixin meglumine $(1,1 \mathrm{mg} / \mathrm{Kg})$ (Hawk, 2005), respectively. After 24 hours, a new subcutaneous administration of physiological solution, meloxicam and flunixin meglumine was performed.

Seven days after the second administration was collected new blood sample. The material was stored in tubes with anticoagulant (EDTA) and centrifuged at $1000 \mathrm{~g}$ for 12 minutes for extraction of plasma and subsequent detection of levels of urea and 
creatinine. For the quantification of urea and creatinine in $\mathrm{mg} / \mathrm{dL}$, enzymatic colorimetric tests were used.

The results were submitted to the Lilliefors test. Once the data was presented in normal distribution, Twoway ANOVA test was used to test the null hypothesis of equal means of urea and creatinine in GC, ME and FM at the initial and final analysis period. In situations of statistical significance, the Least Square Difference (LSD) test was used for comparison between groups. A significance level $\leq 0.05$ was used in all tests.

\section{RESULTS}

The analysis of urea values showed statistically significant differences $(P<0.05)$ between groups in the final period of experimentation (F2, $126=6.9628 ; P=0.00135)$. It was found that the mean values of urea were considered equivalent between the groups in the early period of experimentation, indicating that the three groups were equivalent with regard to renal physiology (Fig. 1). However, in the final period of experimentation, FM and ME groups had a significantly higher mean than the $C G \quad(P=0.0000$, $P=0.0005$, respectively), but equivalent to each other $(P=0.063)$ (Fig. 1, Table 1).

The analysis of creatinine values showed no statistically differences $(P>0.05)$ between groups in the final period of experimentation (F2, $126=0.04672 ; P=0.95437)$. It was found that the mean values of creatinine were considered equivalent between the groups in all periods of experimentation (Table 1).

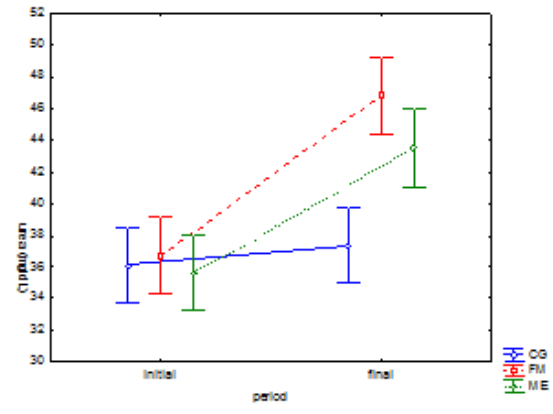

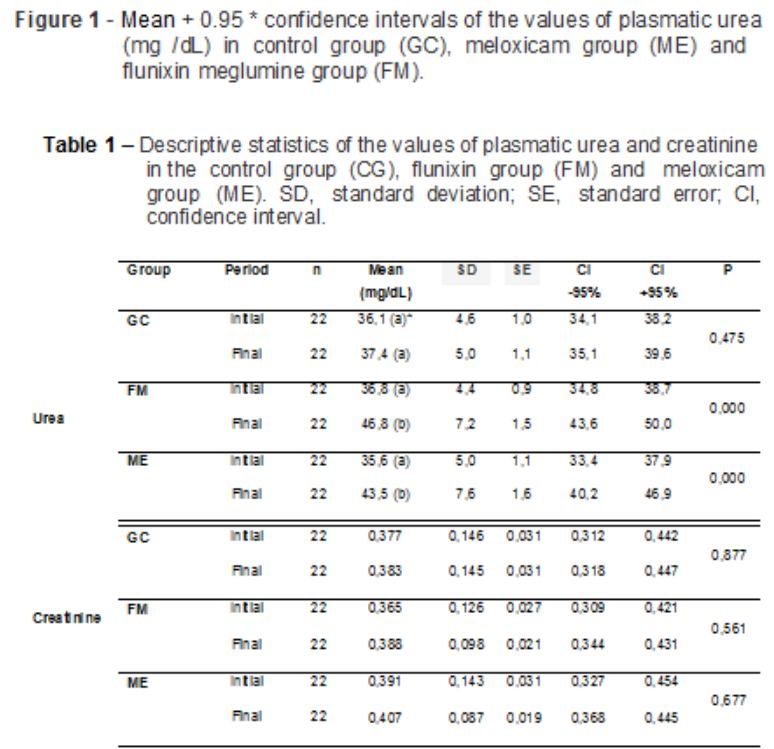

the letters show the result of the LSD test.

\section{DISCUSSION}

Analgesics are often administered to laboratory animals without proper assessment of its efficacy and safety. NSAIDs are a group of anti-inflammatory drugs with great potential to act as painkillers when opioids are contraindicated. However, the doses indicated for other species may result in inadequate analgesia or serious side effects since there is little information on the effects of these compounds on the metabolism of laboratory animals (Liles \& Flecknell, 1992; King \& Miller, 1997).

In this study we used the doses recommended in the literature aiming to obtain results that could indicate the effect of therapeutic doses on renal function in Wistar rats. The dose of flunixin meglumine indicated by Hawk et al. (2005) varies from 1.1 to $2.5 \mathrm{mg} / \mathrm{kg}$ while the dose of meloxicam cited by 
Viana (2007) is $2 \mathrm{mg} / \mathrm{kg}$ for mice. The literature does not describe the specific dose for rats, since the use of analgesics for rodents in routine laboratories is recent and has become an ethical requirement to conduct studies (Hawk et al., 2005).

NSAIDs may interfere with the autoregulation of renal blood flow and precipitate renal hypoperfusion, and should be used with caution in patients with mild hypovolemia and hypotension (Teixeira, 2010). Other adverse effects include inhibition of the biosynthesis of prostaglandin E2 and 12 involved in the maintenance of blood and renal vasodilatation compensating change that occurs in response to the action of norepinephrine and angiotensin II (Hinz et al., 2006). Angiotensin II is primarily responsible for the maintenance of renal perfusion and glomerular filtration because it causes increased resistance of the efferent glomerular arteriole and stimulation of intrarenal vasodilating prostaglandins (Mindell \& Chertow, 1997).

Prostaglandins

and thromboxanes are also mediators of the inflammatory response and participate in pathophysiological processes in multiple organs and systems, thus interrupting its production by NSAIDs may impair renal blood flow leading to increased ischemic lesions (Hilário et al., 2006; Hinz et al., 2006; Chahade et al., 2008) and nephrotoxicity (Ruiz, 2002). Especially in the urinary system, prostaglandins PGE 2 and PGI 2 infused directly into the renal arteries increase renal plasma flow and hence the rate of glomerular filtration rate (Wannmacher \& Ferreira, 2006).

There are three forms of the enzyme cyclooxygenase, COX-1, COX2 and COX-3 (Chahade et al., 2008). COX-1 is a constitutional enzyme and is involved in the homeostasis of many tissues. COX-2 is an enzyme that produces inflammatory mediators of inflammation when induced by activated inflammatory cells (Hinz et al., 2006). A variant of the gene for COX-1 is newly discovered, called COX-3. Its specific function remains unknown (Miller et al., 1978; Hinz et al., 2006). All three isoforms are selectively inhibited by NSAIDs (Chahade et al., 2008).

NSAIDs used in this study were meloxicam and flunixin meglumine and both can be used to promote analgesia in experimental animals. The side effects attributed to the use of meloxicam are decrease in renal blood flow, gastrointestinal ulceration and inhibition of platelet aggregation (Teixeira, 2010). It was the first antiinflammatory marketed medication developed from a molecule inhibitor of COX-2, maintaining a partial blocking of COX-1 (Chahade et al., 2008). The preferential inhibition of prostaglandinrelated COX-2 assigned to this drug reduces the occurrence of gastrointestinal side effects compared to the inhibition produced by less specific NSAIDs (Cooper et al., 2009) although it retains some activity against COX-1 (Furst, 1997; Suckow et al., 2006). But the selective COX 2 has shown nephrotoxic effects compared with nonselective (Perazella \& Tray, 2001).

The flunixin meglumine is a potent COX inhibitor with analgesic and antipyretic action. It is considered a good analgesic for acute pain control and postoperative been widely used in the treatment of infectious diseases, inflammation, fever, pain, visceral and skeletal muscle in cattle, pigs, horses and dogs (Taylor et al., 1994; Pulz et al., 2005; Avila, 2010). However, there is no clinical experience in laboratory animals comparable to that achieved in pets and farm animals. Side effects commonly attributed to the use of FM are ulcerative character throughout the alimentary canal. These effects are caused by COX inhibition and, consequently, by the reduced production of prostaglandins 
(Hinz et al., 2006; Wannmacher \& Ferreira, 2006; Chahade et al., 2008).

According to the results obtained in this study, it was observed that the use of $1.1 \mathrm{mg} / \mathrm{kg}$ flunixin meglumine and $2 \mathrm{mg} / \mathrm{kg}$ meloxicam, caused a significant increase in plasma urea level in the treated animals compared to the control group, however creatinine values showed no statistically differences $(P>0.05)$ between groups in the final period of experimentation.

The hyperuremia is one of the main laboratory findings in patients with renal insufficiency and is directly related to the deficiency in nitrogen excretion by the kidneys (Schossler et al., 2001). The increase in plasma urea can be used as an indicator of renal function, since approximately $40 \%$ of urea is reabsorbed by the renal tubules (Alencar et al., 2002).

As the creatinine excretion occurs by kidneys, this metabolite is considered the gold standard for measuring renal function. The increase in serum creatinine may indicate impairment kidney function (Bush, 2004). In this study, the mean values of creatinine were considered equivalent between the groups in all periods of experimentation. In pre-renal ARF, when the causative agent is the use of NSAIDs, the clearance of urea falls rapidly in relation to creatinine clearance because there is retrograde spread of the filtered urea and not creatinine (Chertow et al., 1995) and increases proportionally to the decrease of functional nephrons (Guyton \& Hall, 2011). In this case the urea, not creatinine, may be a reliable parameter for diagnosis of ARF.

The use of flunixin meglumine and meloxicam in the conditions described in this study caused changes in plasma urea concentration of the treated mice when compared with the control group. At the beginning of the study, the mean values of urea were similar in all groups, demonstrating equivalence of renal function in the animals. Nevertheless, at the end of the experimental period the animals that received flunixin and meloxicam showed means significantly higher than the control group $(P=0.0000, \quad P=0.0005$, respectively), but equivalent to each other $(P=0.063)$. Given that urea may increase with dehydration, the water consumption of each animal was measured and showed no significant changes (data not shown).

Rats, especially

females (Giesbrecht \& Zyngier, 1979), have shown greater susceptibility to the effects of NSAIDs than the mouse and guinea pig (King \& Miller, 1997) and it can be assumed that the route of administration is a relevant factor for the effect of the drug on renal physiology. In the study by Barbosa et al. (2010) no changes were observed in the kidneys of rats given dosages of meloxicam 2 and $10 \mathrm{mg} / \mathrm{kg}$ intragastrically which may suggest that there was a considerable loss of the drug in its first passage through the liver before being absorbed into the systemic circulation.

The most common route of administration is oral, but involves the longer path and complicated for access tissues since the first pass metabolism in the intestine or liver limits the effectiveness of many drugs taken by this route (Mycek et al., 1998). Furthermore, it should resist the digestive acids across the gastrointestinal mucosa before being absorbed into the circulatory system. The oral route allows the active drug to be absorbed more gradually minimizing the adverse effects. The subcutaneous route allows more rapid absorption and it is proportional to blood flow. The drug administered by this route passes through the capillary endothelium and reaches the bloodstream, ensuring a 
higher absorption (Giesbrecht \& Zyngier, 1979).

According Wannmacher and Ferreira (2006), the absorption of a drug influences the beginning and intensity of the pharmacological effect. The evaluation of the pharmacokinetic profile of meloxicam in different species showed that in rats, meloxicam is concentrated primarily in the kidneys and liver similar to what occurs in humans (Engelhardt, 1996; Busch et al., 1998). In dogs, meloxicam has a broad range of security even when there is prolonged use, however, like other NSAIDs, can cause gastrointestinal toxicity (Fish et al., 2008).

In the literature, numerous experiments are found that evaluate the efficacy of flunixin meglumine in large animals including oral ulcers, gastric and duodenal necrosis, renal and hematological diseases (Macallister et al., 1993; Welsh \& Nolan, 1995; Beretta et al., 2005). Pulz et al. (2002) suggested that flunixin is capable of causing renal ischemia in dogs due to drug interactions with other anesthetics, but there are few studies that evaluate possible adverse effects caused by it in other animals, especially in laboratory animals.

Elmas et al. (2008) evaluated the pharmacokinetics of flunixin meglumine in healthy and endotoxemic rabbits and observed that this drug can be coadministered for the treatment of endotoxemia in these animals. Liles and Flecknell (1992), Arumugam et al. (2003), Martin and Stewart (2003) believe that this drug may be an alternative for the treatment of pain in rodent species. However, Taylor et al. (1994) suggest that differences in halflife of NSAIDs among species may be an impediment to the extrapolation of results obtained in different species. Therefore, the use of NSAIDs in laboratory animals should not be done under any circumstances. One should take into account their effectiveness in specific clinical situations and adjust the dose in a treatment regimen preestablished (Liles \& Flecknell, 1992).

\section{CONCLUSION}

The results of this study suggest that the use of meloxicam and flunixin meglumine at doses recommended in the literature to laboratory mice, specifically, caused increase in the plasma urea level, but the values of the plasma creatinine were considered equivalent between the groups in all periods.

If necessary, the use of these drugs should be done with caution because further studies in Wistar rats are needed in order to evaluate the dosage of these drugs in experimentation animals.

\section{INFORMATIVE NOTES}

This study was approved by the Committee on Animal Research and Ethics, number 10/2011.

\section{REFERENCES}

ALENCAR, M.M.A; PINTO, M.T.; OLIVEIRA, D.M. et al.. Evaluation of the pharmacologic activity of Meloxicam on renal function in dogs. Ciência Animal, v.12, n.1, p. 25-33, 2002.

ARUMUGAM, T.V.; ARNOLD, N.; PROCTOR, L.M. et al. Comparative protection against rat intestinal reperfusion injury by a new inhibitor of SPLA2, COX-1 and COX-2 selective inhibitors, andan LTC4 receptor antagonist. British Journal of Pharmacology, v.140, n.1, p.71-80, 2003.

ÁVILA, L.C. Índice Terapêutico Veterinário. Rio de Janeiro: Epub, 2010. 264p.

BARBOSA, C.M.; SAKATE, M.; CAMPLESI A.C. et al. Avaliações hematológicas e bioquímicas do uso de diclofenaco de sódio, meloxicam e firocoxibe em ratos. Brazilian Journal of Veterinary Animal Science, v.47, n.2, p.118-126, 2010. 
BERETTA, C.; GARAVAGLIA, G.; CAVALLI, M. COX-1 and COX-2 inhibition in horse blood by phenylbutazone, flunixin, carprofen and meloxicam: an in vitro analysis.

Pharmacological Research, v.52, n.4, p.302306, 2005.

\section{BUSH, B.M. Interpretação de Resultados Laboratoriais para Clínico de Pequenos} animais. São Paulo, Roca, p. 169 - 232, 2004.

BUSCH, U.; SCHMID, J., HEINZEL, H. et al. Pharmacokinetics of meloxicam in animals and the relevance to human. Drug Metabolism and Disposition, v.26, n.6, p.576-584, 1998.

CHAHADE, W.H.; GIORGI, R.D.N.; SZAJUBOK, J.C.M. Antiinflamatórios não hormonais. Einstein, v.6, n.1, p.166-174, 2008.

CHERTOW, G.M.; CHRISTIANSES, C.L.; CLEARY, P.D. et al. Prognostic stratification in critically ill patients with acute renal failure requiring dialysis. Archives of Internal Medicine, v.155, n.14, p.1505-1511, 1995.

COOPER, C.S.; PATE, K.A.M.; BARAT, C.E. et al. Comparison of Side Effects between Buprenorphine and Meloxicam Used Postoperatively in Dutch Belted Rabbits (Oryctolagus cuniculus). Journal of the American Association for Laboratory Animal Science, v.48, n.3, p.279-285, 2009.

COSTA, J.A.C.; VIEIRA NETO, O.M.; MOYSÉS, M. Acute renal failure. Medicina, v.36, p.307324, 2003.

ELMAS, M.; YAZAR, E.; UNEY, K.; KARABACAK, A.E. Pharmacokinetics of enrofloxacin and flunixin meglumine and interactions between both drugs after intravenous co-administration in healthy and endotoxaemic rabbits. The Veterinary Journal, v.177, n.3, p.418-424, 2008.

ENGELHARDT, G. Pharmacology of meloxicam, a new non-steroidal anti-inflammatory drug with an improved safety profile through preferential inhibition of COX-2. British Journal of Rheumatology, v.35, n.1, p.4-12, 1996.

FISH, R. E.; BROWN, J. P.; DANNEMAN, A.Z. Anesthesia and analgesia in Laboratory animal. Philadelphia: Elsevier, 2008. 450p.

FURST, D.E. Meloxicam: selective COX-2 inhibition in clinical practice. Arthritis and Rheumatism, v.126, n.6, p.21-27, 1997.
GIESBRECHT, A.M.; ZYNGIER, S.B. Absorção e distribuição de drogas. In: ZANINI, A.C.; OGA, S. Farmacologia Aplicada. São Paulo: Atheneu, 1979. 305 p.

GUYTON, A.C.; HALL, J.E. Regulação do equilíbio ácido básico; micção; doença renal. In: Fisiologia Humana e Mecanismos das Doenças. Rio de Janeiro: Elsevier, 2011. 1216p.

HAWK, C.T.; LEARY, S.L.; MORRIS, T.H. Formulary for laboratory animals. lowa: Blackwell Publishing, 2005. 203p.

HILÁRIO, M.O.E.; TERRERI, M.T., LEN, C.A. Nonsteroidal anti-inflammatory drugs: cyclooxygenase 2 inhibitors. Jornal de Pediatria, v.82, n.5, p.206-212, 2006.

HINZ, B.; DORMANN, H.; BRUNE, K. More pronounced inhibition of cyclooxygenase 2, increase in blood pressure, and reduction of heart rate by treatment with diclofenac compared with celecoxib and rofecoxib. Arthritis \& Rheumatism, v.54, n.1, p.282-291, 2006.

HUEZA, I.M. Avian pharmacology: employing anti-inflammatory drugs in wild birds. Ars Veterinaria, v.24, n.1, p.15-24, 2008.

INSTITUTE OF LABORATORY ANIMAL RESEARCH, Committee for the Update of the Guide for the Care and Use of Laboratory Animals. Guide for the care and use of laboratory animals. 8th edition, Washington, DC: National Academies Press. 220 p. (2011)

KING, C.S.; MILLER, R.T. Fatal perforating intestinal ulceration attributable to flunixin meglumine overdose in rats. Laboratory Animals, v.47, n.2, p.205-208, 1997.

LILES, J.H; FLECKNELL, P.A. The use of nonsteroidal anti-inflammatory drugs for the relief of pain in laboratory rodents and rabbits.

Laboratory Animals, v.10, n.4, p.241-255, 1992.

MACALLISTER, C.G.; MORGAN, S.J.; BORNE, A.T.; POLLET, A.R. Comparison of adverse effects of phenylbutazone, flunixin meglumine, e ketoprofen in horses. Journal of the American Veterinary Medical Association, v.202, n.1, p.71-77, 1993.

MILLER, T.R.; ANDERSON, R.J.; LINAS, S.L. et al. Urinary diagnostic indices in acute renal 
failure. Annals of Internal Medicine, v.89, p.4750, 1978.

MINDELL, J.A.; CHERTOW, G.M. A practical approach to acute renal failure. Medical Clinics of North America, v.81, n.3, p.731-748, 1997.

MYCEK, J.M.; HARVEY, R.A.; CHAMPE, P.C. Absorção, Distribuição e Eliminação de Fármacos. In: Farmacologia llustrada, Porto Alegre: Artmed, 1998. 370p.

PERAZELLA, M.A.; TRAY, K. Selective cyclooxygenase-2 inhibitors: a pattern of nephrotoxicity similar to traditional no steroidal anti-inflammatory drugs. American Journal of Medicine, v.111, p.64-67, 2001.

PULZ, R.S.; MAIA, J.; PETRUCCI, B.P.L. et al. Evaluation of renal function in dogs that undergo the administration of Flunixin Meglumine during general anaesthesia. Veterinária em Foco, v.3, n.1, p.29-36, 2005.

RUIZ, A.A.P.; MANTECÓN, A.L.L.; LEÓN, I.G. Antiinflamatorios no esteroideos (AINES) Consideraciones para su uso estomatológico.

Revista Cubana de Estomatología, v.39, n.2, p.119-138, 2002.

SCHOSSLER, D.; ALIEVI, M.M.; EMANUELLI, J.E.; SCHOSSLER, J.E. Função renal de cães tratados com doses terapêuticas de flunixin meglumine e ketoprofen durante o trans e pósoperatório. Acta Cirurgica Brasileira, v.16, n.1, p.46-51, 2001.

STEWART, S.A.; MARTIN, W.J. Evaluation of Postoperative Analgesia in a Rat Model of Incisional Pain. Contemporary Topics in Laboratory Animal Science, v.42, n.1, p.28-34, 2003.

SUCKOW, M. A.; WEISBROTH, H.; FRANKLIN, C.L. The laboratory rat. Boston: Elsevier, 2006. 350p.

TAYLOR, J.G.; WINNARD, R.; JEFFERIES, R.; LEES, P. Flunixin in the cat: a pharmacodynamic, pharmacokinetic and toxicological study, British Veterinary Journal, v.150, n.3, p.253-262, 1994.

TEIXEIRA, F.M. Avaliação comparativa do efeito de fármacos antiinflamatórios com a acupuntura no modelo de dor pós-incisional em ratos. 2010. Rio de Janeiro, $87 \mathrm{f}$.

Dissertação (Mestrado em Medicina Veterinária) - Curso de Pós-graduação em Ciências
Veterinárias, Universidade Federal do Rio de Janeiro.

VIANA, F.A.B. Guia Terapêutico Veterinário. Lagoa Santa: Gráfica e Editora CEM, 2007, $324 p$.

WANNMACHER, L.; FERREIRA, M.B.C. Antiinflamatórios não-esteróides. In: FUCHS F.D.; WANNMACHER, L. FERREIRA, M.B.C. Farmacologia Clínica: Fundamentos da Terapêutica Racional. Rio de Janeiro, 2006, 303p.

WELSH, E.M., NOLAN, A.M. Effect of flunixin meglumine on the thresholds to mechanical stimulation in healthy and lame sheep.

Research in Veterinary Science, v.58, n.1, p.61-66, 1995. 